sent to Prof Leninha Valério do Nascimento - Editor-in-Chief ANAIS BRASILEIROS

Commentary

\title{
BEAUTY IS SKIN DEEP
}

I should like to offer a commentary upon receipt of the beautifully styled Anais Brasileiros vol $77 \mathrm{n} .2$ issue these days. I receive the journal for quite some time but only sporadically. I cannot be sure therefore since when the new style and "skin" of the issues is produced. Anyway, it convincingly illustrates what the editorial by Elemir Macedo de Souza expresses on the first pages, - beauty is reflected even on the paper of the journal. ${ }^{1}$

Cosmetics gain ever more importance in dermatology because beauty is in demand world wide. To deliver this beauty skin deep is one of the problems we face. We have just stressed that question elsewhere. ${ }^{2}$ Writing from northerly latitudes we are aware that the phototype of the patient plays an increasingly important role. The fairer the person the more he/se desires to be tanned, a paradox created by the fashion of the last hundred years. Brazil is in a much more favorable position in this respect because the beautiful tan of skin need not be created artificially, it is provided by mother nature also to the clines of man with a stronger Caucasian background. Fortunately however, the ideals of beauty have changed concomitantly over the 20th century, and today's world is more aware of the complexion of the Queen of Sheba ${ }^{3}$ of the culture of négritude, ${ }^{4}$ of a black venus, - the fashion world is proof of that, - than previous centuries used to be. This is a positive side effect of the trends initiated by Coco Chanel and others decades ago. Dermatology in any case must deliver this beauty skin deep, a beauty which goes beyond the epidermis because photodamage of collagen is to be avoided or reduced.

Joseph Plenck (1735-1807) $)^{5}$ is nicely addressed in the editorial. Sitting- better say, having had the privilege to sit - in Plenck's chair in Vienna up to retirement last year confers a particular mood to my words. He was born Viennese and died here, living next to Wolfgang Amadeus Mozart in downtown Vienna and being likened to him in his productivity. ${ }^{6}$ His famous treatise he wrote while still professor in Hungary where he was sent by Empress Maria Theresa when she founded a new university in Nagyszombat/Tyrnau/ Trnava, Slovakia of today. In his baptismal record in the metropolitan parish of St. Stephan in Vienna he is listed as Joseph Andreas. In the death protocol as Jacob. These were the vicissitudes of the time when first names were many and changed more frequently and easily. (He was professor and secretary of the Imperial Military Medical School, the historic building (1785) of which today houses the Institute for the history of Medicine).

I am a medico-historian, also a dermatologist and former department head at Hebrew University in Jerusalem. Franjo Kogoj (1884-1983) lived and held his chair in dermatology in Zagreb, Croatia, and I had the privilege to know him personally and to work in dermatopathology for many years. A reference to the article by Joel Schwartz et al may be permitted in this regard. ${ }^{7}$ Psoriasis is 200 years old as a distinct clinical entity (Robert Willan 1801), parapsoriasis is just 100 years old (Jean-Anne-Louis Brocq in April 1902). These facts should further stimulate reference to such classical dermatoses. Psoriasis ostracea or rupiosa is a well known clinical variety. The histopathology depicted in Fig. ${ }^{3}$ of the above article is typical but, I would rather call this a Munro microabscess plus a spongiforme pustule, unless the lower half of the photograph depicts the tip of an elongated dermal papilla, a fact than cannot be judged from the photograph, the whole slide would be needed. Munro, an Australian, described the abscesses in psoriasis eponymously named after him, just when he left Vienna for Paris in the late nineties of the 19th century. ${ }^{8}$ Kogoj described his spongiforme pustule in 1927 in acrodermatitis continua Hallopeau. ${ }^{9}$ Both groups of diagnoses - psoriais and acrodermatitis and their potential relation, are well worth some discussion, as much as are the two types of collections of leucocytes within the epidermis and their course. Interestingly and well known to dermatopathologists, Pautrier's microabscesses are still another variety of (malignant) cell accumulations in the epidermis, in mycosis fungoides for that matter. ${ }^{10}$ The latter do not pose a problem in differential diagnosis in this regard.

A recent book details many of the stories in relation to eponyms and famous dermatologist and may be recommended to the reader. ${ }^{11}$ 


\section{REFERÊNCIAS / REFERENCES}

1. Souza EM: A beleza da dermatologia. Editorial An Bras Dermatol 2002; 77:125-6

2. Fatovi_-Feren_i_S Dürrigl MA Holubar K: Beauty: Soul or Surface. J Cosmet Dermatol (in press)

3. Holubar K : A Hail to the Chief. Letter to the Editor. J Invest Dermatol 2002; 119: n.1 (July issue )

4. Holubar,K.: Black Skin and the Ideal of Beauty. J. Invest.Dermatol. 1997;108:813-814

5. Holubar K Frankl: Joseph Plenck (1735-1807). A forerunner of modern European dermatology J Am Acad Dermatol 1984; 10:326-332

6. Crissey JT Parish LC: The dermatology and syphilography of the nineteenth century. Praeger New York 1981

7. Bernardi CDV Schwartz J Lecompte SM Trez EG: Psoríase ostrácea - relato de caso. An Bras Dermatol 2002; 77:207-210

8. Johnson A:William John Munro (1863-1908). Am J Dermatopathol 1983; 5:477-8

9. Kogoj F: Un cas de maladie de Hallopeau. Acta derm-venereol 1927/28; 8:1-12

10. Schmidt-Skrabs CC: Pautrier's Microabscesses: A Historical Note. Am J Dermatopathol 2000; 6:555

11. Crissey JT Parish LC Holubar K: Historical atlas of dermatology and dermatologists. Parthenon, London 2002

\author{
MAILING ADDRESS: \\ Karl Holubar MD FRCP \\ Institute for the History of Medicine \\ Währinger Strasse 25 \\ A-1090 Vienna, Austria \\ KH.histmed@univei.ac.at
}

